\title{
Study on air pollutant emission inventory of port operation machinery in container terminal
}

\author{
Mingjun $\mathrm{Li}^{1,2 *}$, Xiaowen Yang ${ }^{1,2}$, Yue $\mathrm{Li}^{1,2}$, Liguo Zhang ${ }^{1,2}$, Zhiyuan Bao ${ }^{1,2}$, Yonglin \\ Zhang $^{1,2}$, Jinxiang Cheng ${ }^{1,2}$, and Honglei $\mathrm{Xu}^{1,2}$ \\ ${ }^{1}$ Transport Planning and Research Institute, Ministry of Transport, Beijing, China 100028 \\ ${ }^{2}$ Transport Planning and Research Institute, Ministry of Transport, Laboratory of Transport Pollution \\ Control and Monitoring Technology, Beijing 100028, China
}

Keywords: air pollutant emission inventory, port operation machinery, container terminal.

\begin{abstract}
In this paper, a calculation method system of air pollutant emission inventory of port operation machinery in container terminal is established. Through the special investigation of port machinery manufacturers and engine manufacturers, the average load rate data of main port machinery engines in domestic container terminals are obtained. Taking a domestic container terminal as an example, the dynamic method and fuel consumption method are used to calculate the air pollutant emission inventory of port operation machinery, and the calculation results of the two methods are compared and analyzed. The results show that the calculation method system of air pollutant emission inventory of port operation machinery established in this paper is highly practical, and the calculation results obtained by the two methods are very close.
\end{abstract}

\begin{tabular}{ll}
\multicolumn{2}{c}{ Abbreviations } \\
\hline $\mathrm{SO}_{2}$ & Sulfur dioxide \\
$\mathrm{NO}_{\mathrm{x}}$ & Nitrogen oxide \\
$\mathrm{PM}$ & Particulate matter \\
$\mathrm{HC}$ & Hydrocarbons \\
$\mathrm{CO}$ & Carbon monoxide \\
\hline
\end{tabular}

\section{Introduction}

Compiling emission inventory of port is an important basis for port air pollution control. At present, research methods for port operation machinery emission inventory mainly include dynamic method and fuel consumption method. The research on the emission inventory of port operation machinery in China started relatively late, and the foreign basic emission factor data are often used in the localization application of the model, which leads to great uncertainty. The activity level data of dynamic method include the number of port operation machinery, rated power, average load rate of engine, working time and emission

\footnotetext{
*Corresponding author: limingjun_83@126.com
} 
standard. According to the investigation of typical container terminals, the above data can be obtained from port statistical data except for the average load rate of engines. The activity level data of fuel consumption method include the quantity, rated power, emission standard of all kinds of port operation machinery and the fuel consumption of each machinery. The above data can be obtained through port statistical data. From the above analysis, it can be seen that the average load rate of the engine is the key parameter in the calculation of port operation machinery emission inventory by dynamic method.

\section{Research status of emission inventory of port operation machinery}

Dynamic method and fuel consumption method have been applied in China to compile emission inventory of port operation machinery. Dynamic method is based on the power and operation time of port machinery, combined with different machinery emission factors to calculate the emission inventory of air pollutants. Peng Yiqiang et al. from Hohai University corrected the emission factor by investigating and analyzing the holding quantity, activity level and equipment parameters of the operating machinery in container terminals, and established a "bottom-up" dynamic method based on the activity level of the mechanical engine in container port to establish a calculation model of the atmospheric pollutant emission inventory of container port ${ }^{[1]}$.Taking Nanjing Longtan Container Port (NPLC) as a case, the emission inventory is constructed. The results show that the total emissions of NPLC port operation machinery in 2014 are 4.25 tons of $\mathrm{PM}_{10}, 3.91$ tons of $\mathrm{PM}_{2.5}, 82.98$ tons of $\mathrm{NO}_{x}, 1.06$ tons of $\mathrm{SO}_{2}, 23.84$ tons of $\mathrm{CO}$ and 16.39 tons of $\mathrm{HC} . \mathrm{NO}_{\mathrm{x}}$ is high-value emission pollutant; The port machinery is the largest source of PM and HC in comparison with other port area emitters. Compared with the 2013 NPLC-based study on fuel consumption, the activity-based emissions were lower.

The fuel consumption method is a method to calculate the emission inventory of air pollutants based on the survey data of fuel consumption of port operation machinery combined with different machinery emission factors. Based on the existing statistics of port machinery in China, the activity level data of the fuel consumption method is easier to obtain than that of the dynamic method. Therefore, this method is mostly used in the emission inventory research of the existing port machinery in China. On the basis of comprehensive analysis of domestic and foreign literature, Tan Hua et al. from Shanghai Environmental Monitoring Center combined with the investigation results of various types of port machinery in Shanghai port, corrected the calculation method of pollutant emission of port machinery, and obtained the statistical fuel volume of Shanghai port by using the method of field investigation, and established the air pollutants of Shanghai port operation machinery in 2010 Emission inventory ${ }^{[2]}$. The results show that the total emission of port machinery from the 106 enterprises surveyed is 2900 tons of $\mathrm{NO}_{\mathrm{x}}, 400$ tons of $\mathrm{VOC}_{\mathrm{s}}, 800$ tons of $\mathrm{CO}, 130$ tons of $\mathrm{PM}_{2.5}$ and 5.8 tons of $\mathrm{SO}_{2}$. $\mathrm{NO}_{\mathrm{x}}$ is the most characteristic pollutant discharged by the port machinery, and $\mathrm{SO}_{2}$ is the least. Based on the on-site investigation of Nanjing Longtan container port, Jia Xu et al. analyzed the operation mode of container port and estimated the discharge of major air pollutants in the port area in 2013 by using the fuel consumption of port machinery obtained from the investigation ${ }^{[3]}$. The calculation results show that the total emission of various pollutants is 501.73 tons, among which $\mathrm{NO}_{\mathrm{x}}, \mathrm{CO}$ and $\mathrm{SO}_{\mathrm{x}}$ are the main air pollutants, and their emissions are 229.9 tons, 190.5 tons and 17.4 tons respectively. Container loading and unloading bridge is the main source of air pollutants in the port area, accounting for $84 \%$ of the total emissions. Fan Xiaoli, from South China University of Technology, based on the field survey of pearl River Delta ports, proposed a refined estimation method of port machinery emission inventory based on unit operation mode and machine type, and finally established the Pearl River Delta port 
machinery emission inventory in 2014 by using this method ${ }^{[4]}$. The results show that the $\mathrm{SO}_{2}, \mathrm{NO}_{\mathrm{x}}, \mathrm{CO}, \mathrm{PM}_{10}, \mathrm{PM}_{2.5}$ and $\mathrm{HC}$ emitted by port machinery in the Pearl River Delta in 2014 are 633.6 tons, 4610.6 tons, 3391.2 tons, 226.9 tons, 216.0 tons and 728.8 tons respectively. Among them, container terminal is the most important port machinery use place, container special machinery and horizontal transport machinery is the main contribution type of machinery.

Based on the above literature research, it is found that both the dynamic method and the fuel consumption method have great differences in the selection and modification of emission factors and the selection of key factors such as load factors. The calculation process is quite complex and there is no unified standard. The results of the two methods are difficult to be compared directly, and the uncertainty is high. With the refinement of air pollution prevention and control management in China in recent years, the compilation of emission source inventory as a key basic work, it is urgent to deepen the research on the refinement of estimation methods.

\section{The calculation method of emission inventory of port operation machinery}

\subsection{Classification of port operation machinery}

Referring to the second, third and fourth classification in The Technical Guide for The Compilation of Emission Inventory of Air Pollutants from Non-road Mobile Sources (Trial) ${ }^{[5]}$, the three-level classification of port operation machinery in container terminals is carried out. The first level classification is divided into quayside container crane, rail type container gantry crane, rubber-tyred container gantry crane, container front lifting crane, empty container stacker, container straddle carrier, container transfer gantry crane, container forklift, etc. the second level classification is divided into $<37 \mathrm{KW}, 37-75 \mathrm{~kW}$, $75-130 \mathrm{kw}, \geq 130 \mathrm{~kW}$ according to the rated power; the third level is divided into three categories According to the emission standards, the emission standards can be divided into five stages, namely, the first stage, the second stage, the third stage and the fourth stage.

Table 1. Classification of port operation machinery.

\begin{tabular}{ccc}
\hline First level classification & $\begin{array}{c}\text { Secondary } \\
\text { classification }\end{array}$ & Third level classification \\
\hline quayside container crane & & \\
rail type container gantry crane & & China 0 Emission Standard; \\
rubber-tyred container gantry crane & $<37 \mathrm{~kW} ;$ & China 1 Emission Standard; \\
container front lifting crane & $37-75 \mathrm{~kW} ;$ & China 2 emission standard; \\
empty container stacker & $75-130 \mathrm{~kW} ;$ & China 3 emission standard; \\
container straddle carrier & $>130 \mathrm{~kW}$ & China 4 emission standard \\
container transfer gantry crane & & \\
container forklift & & \\
\hline
\end{tabular}

According to the sales date of port operation machinery, the emission standards to be implemented can be determined, as shown in Table 2. The implementation date of China 4 emission standard is determined according to the date in The Revised List of Emission Limits and Measurement Methods of Exhaust Pollutants from Diesel Engines for Non-road Mobile Machinery (China's III and IV stages) (GB 20891-2014) (Draft for comments) ${ }^{[6]}$.

Table 2. Sales date corresponding to discharge standard of port operation machinery. 


\begin{tabular}{ccccc}
\hline China 0 & China 1 & China 2 & China 3 & China 4 \\
\hline \multirow{2}{*}{2008.9 .30} & $2008.10 .1 \sim$ & $2010.10 .1 \sim$ & $2016.4 .1 \sim$ & \multirow{2}{*}{$2020.12 .1 \sim$} \\
\hline
\end{tabular}

\subsection{Dynamic method}

The formula for calculating the air pollutant emission inventory of port operation machinery by dynamic method is shown in the following formula.

$$
E_{i}=\sum_{j} \sum_{k} \operatorname{Pop}_{i, j, k} \times P_{i, j, k} \times L F_{i, j, k} \times E F_{i, j, k} \times A_{i, j, k} \times 10^{-6}
$$

where:

$E_{i}$ - total discharge amount of pollutant $i$ of port operation machinery, T;

Pop - the quantity of some port operation machinery, vehicle;

$P$ - rated power of certain port operation machinery, $\mathrm{kW}$;

$L F$ - the average load rate of a certain port operation machinery engine, dimensionless;

$E F$ - emission factor of certain port operation machinery, $\mathrm{g} / \mathrm{kW} \cdot \mathrm{h}$;

$A$ - working time of certain port operation machinery, $\mathrm{h}$;

$i$ - pollutant types, including $\mathrm{CO}, \mathrm{HC}, \mathrm{NO}_{\mathrm{x}}$ and $\mathrm{PM}$;

$j$ - power section of engine of some port operation machinery;

$k$ - emission standard of certain port operation machinery.

\subsection{Fuel consumption method}

The formula for calculating air pollutant emission inventory of port operation machinery by fuel consumption method is shown in the following formula.

$$
E_{i}=\sum_{j} \sum_{k} P o p_{j, k} \times E F_{i, j, k} \times C F_{j} \times \rho \times 10^{-6}
$$

Where:

$E_{i}$ - total discharge amount of pollutant $i$ of port operation machinery, T;

Pop - the quantity of some port operation machinery, vehicle;

$E F$ - emission factor based on fuel consumption of certain port operation machinery, $\mathrm{g} / \mathrm{kg}$ fuel;

$C F$ - fuel consumption of certain port operation machinery, $\mathrm{L}$;

$\rho$ - fuel density, $\mathrm{kg} / \mathrm{L}$; density of No.0 diesel oil can be taken as $0.83 \mathrm{~kg} / \mathrm{L}$;

$i$ - pollutant types, including $\mathrm{CO}, \mathrm{HC}, \mathrm{NO}_{\mathrm{x}}$ and $\mathrm{PM}$;

$j$ - power section of engine of some port operation machinery;

$k$ - emission standard of certain port operation machinery.

\subsection{Calculation of $\mathrm{SO}_{2}$ emission inventory}

$\mathrm{SO}_{2}$ emission is only related to sulfur content of fuel oil, and its calculation method is relatively simple. The calculation method of $\mathrm{SO}_{2}$ emission is shown in the following formula.

$$
E=2 \times Y \times S \times 10^{-9}
$$


where:

$E$ - total emission of $\mathrm{SO}_{2}, \mathrm{~T}$;

$Y$ - fuel consumption, $\mathrm{kg}$;

$S$ - sulfur content of fuel, $\mathrm{mg} / \mathrm{kg}$.

According to Vehicle Diesel Oil (GB 19147-2016) ${ }^{[7]}$, since January 1, 2019, sulfur content of diesel oil is not more than $10 \mathrm{mg} / \mathrm{kg}$, so the sulfur content of fuel oil is taken as $10 \mathrm{mg} / \mathrm{kg}$.

\section{Emission factor}

\subsection{Emission factor for dynamic method}

The emission factor for dynamic method is shown in Table 3. The recommended values of emission factors for China 0, China 1, China 2 and China 3 refer to the recommended coefficients in The Technical Guide for The Compilation of Emission Inventory of Air Pollutants from Non-road Mobile Sources (Trial). The recommended values of emission factors for China 4 are determined according to the ratio of emission standards of China 4 and China 3 in accordance with the Emission Limits and Measurement Methods of Exhaust Pollutants from Diesel Engines for Non-road Mobile Machinery (China's III and IV stages) (GB 20891-2014) ${ }^{[8]}$ and the recommended values of emission factors of state III.

Table 3. Emission factor for dynamic method of port operation machinery in container terminal $(\mathrm{g} / \mathrm{kW} \cdot \mathrm{h})$.

\begin{tabular}{cccccc}
\hline Power section & Emission standard & CO & HC & NOx & PM \\
\hline \multirow{5}{*}{$<37 \mathrm{~kW}$} & China 0 & 6.5 & 1.3 & 10.5 & 1.2 \\
& China 1 & 6.5 & 1.3 & 10.5 & 1 \\
& China 2 & 6.5 & 1.3 & 10.5 & 0.95 \\
& China 3 & 5 & 1.1 & 6 & 0.55 \\
& China 4 & 5 & 1.1 & 6 & 0.55 \\
& China 0 & 6.5 & 1.3 & 10.5 & 1 \\
& China 1 & 6.5 & 1.3 & 9.2 & 0.85 \\
$37-75 \mathrm{~kW}$ & China 2 & 5 & 1.3 & 7 & 0.4 \\
& China 3 & 4.5 & 1 & 3.5 & 0.35 \\
& China 4 & 4.5 & 1 & 3.5 & 0.022 \\
& China 0 & 5 & 1.3 & 10 & 0.8 \\
$75-130 \mathrm{~kW}$ & China 1 & 5 & 1 & 9.2 & 0.7 \\
& China 2 & 5 & 1 & 6 & 0.3 \\
& China 3 & 4.5 & 0.8 & 2.8 & 0.25 \\
& China 4 & 4.5 & 0.7 & 2.45 & 0.021 \\
& China 0 & 5 & 1.3 & 10 & 0.7 \\
& China 1 & 5 & 1.3 & 9.2 & 0.54 \\
& China 2 & 3.5 & 1 & 6 & 0.2 \\
& China 3 & 3 & 0.8 & 2.8 & 0.18 \\
& China 4 & 3 & 0.44 & 1.54 & 0.023 \\
\hline
\end{tabular}

\subsection{Emission factor for fuel consumption method}

The emission factor for fuel consumption method is shown in Table 4. The recommended values of emission factors for China 0, China 1, China 2 and China 3 refer to the 
recommended coefficients in The Technical Guide for The Compilation of Emission Inventory of Air Pollutants from Non-road Mobile Sources (Trial). The recommended values of emission factors for China 4 are determined according to the ratio of emission standards of China 4 and China 3 in accordance with the Emission Limits and Measurement Methods of Exhaust Pollutants from Diesel Engines for Non-road Mobile Machinery (China's III and IV stages) (GB 20891-2014) and the recommended values of emission factors of state III.

Table 4. Emission factor for fuel consumption method of port operation machinery in container terminal. ( $\mathrm{g} / \mathrm{kg}$ fuel)

\begin{tabular}{cccccc}
\hline Power section & Emission standard & CO & HC & NOx & PM \\
\hline \multirow{5}{*}{$<37 \mathrm{~kW}$} & China 0 & 26 & 5.2 & 42 & 4.8 \\
& China 1 & 26 & 5.2 & 42 & 4 \\
& China 2 & 26 & 5.2 & 30 & 3.8 \\
& China 3 & 22.75 & 5 & 27.3 & 2.5 \\
& China 4 & 22.75 & 5 & 27.3 & 2.5 \\
& China 0 & 28.2 & 5.65 & 45.6 & 4.34 \\
$37-75 \mathrm{~kW}$ & China 1 & 28.2 & 5.65 & 39.9 & 3.69 \\
& China 2 & 21.7 & 5.65 & 30.4 & 1.74 \\
& China 3 & 21.42 & 4.76 & 16.67 & 1.66 \\
& China 4 & 21.42 & 4.76 & 16.67 & 0.104 \\
& China 0 & 23.8 & 6.19 & 47.6 & 3.81 \\
$75-130 \mathrm{~kW}$ & China 1 & 23.8 & 6.19 & 43.8 & 3.33 \\
& China 2 & 23.8 & 4.76 & 28.6 & 1.43 \\
& China 3 & 21.96 & 3.91 & 13.66 & 1.22 \\
& China 4 & 21.96 & 3.42 & 11.95 & 0.102 \\
& China 0 & 25 & 6.5 & 50 & 3.5 \\
& China 1 & 25 & 6.5 & 46 & 2.7 \\
& China 2 & 17.5 & 5 & 30 & 1 \\
& China 3 & 15 & 4 & 14 & 0.9 \\
& China 4 & 15 & 2.2 & 7.7 & 0.113 \\
\hline
\end{tabular}

\section{Activity level data}

\subsection{Statistics of Port Enterprise}

A special investigation on a domestic container terminal was carried out, and the types and parameters of its basic operation machinery in 2019 were mastered. The statistical analysis was carried out according to the three-level classification of container terminal port operation machinery, as shown in Table 5.

Table 5. Basic parameters of operation machinery in a container terminal.

\begin{tabular}{cccccc}
\hline Machinery & $\begin{array}{c}\text { Power } \\
\text { section }\end{array}$ & $\begin{array}{c}\text { Emission } \\
\text { standard }\end{array}$ & Number & $\begin{array}{c}\text { Annual working } \\
\text { hours(h) }\end{array}$ & $\begin{array}{c}\text { Annual fuel } \\
\text { consumption(t } \\
\text { ) }\end{array}$ \\
\hline rubber-tyred & $75-130 \mathrm{~kW}$ & China 2 & 5 & 35277 & 381.7 \\
$\begin{array}{c}\text { container } \\
\text { gantry crane }\end{array}$ & $>130 \mathrm{~kW}$ & China 3 & 4 & 1916 & 75.4 \\
& China 1 & 21 & 158276 & 1597.7 \\
China 2 & 29 & 220713 & 2293.0 \\
lifting crane & Subtotal & China 3 & 17 & 126946 & 1121.4 \\
& & & 76 & 543128 & 5469.2 \\
& & China 2 & 5 & 17075 & 160.0
\end{tabular}




\begin{tabular}{|c|c|c|c|c|c|}
\hline \multirow{2}{*}{$\begin{array}{l}\text { empty } \\
\text { container } \\
\text { stacker }\end{array}$} & Subtotal & China 2 & $\begin{array}{l}5 \\
9\end{array}$ & $\begin{array}{l}17075 \\
44563\end{array}$ & $\begin{array}{l}160.0 \\
295.8\end{array}$ \\
\hline & $>130 \mathrm{~kW}$ & China 3 & 13 & 70265 & 533.5 \\
\hline \multirow{7}{*}{$\begin{array}{c}\text { container } \\
\text { forklift }\end{array}$} & Subtotal & & 22 & 114828 & 829.3 \\
\hline & & China 2 & 8 & 8886 & 35.0 \\
\hline & $3 /-13 \mathrm{KW}$ & China 3 & 8 & 5748 & 12.8 \\
\hline & $75-130 \mathrm{~kW}$ & China 3 & 2 & 683 & 2.4 \\
\hline & $>130 \mathrm{~kW}$ & China 1 & 1 & 517 & 1.2 \\
\hline & & China 2 & 1 & 1008 & 3.9 \\
\hline & Subtotal & & 20 & 16842 & 55.3 \\
\hline
\end{tabular}

\subsection{Average load rate of engine for port operation machinery}

A special investigation has been conducted on port machinery manufacturers and engine manufacturers, and the average load rate data of main port operating machinery engines in domestic container terminals are obtained. The results are shown in Table 6.

Table 6. Average engine load rate of port operation machinery in container terminal.

\begin{tabular}{ccccc}
\hline Machinery & $\begin{array}{c}\text { container gantry } \\
\text { crane }\end{array}$ & $\begin{array}{c}\text { container front lifting } \\
\text { crane }\end{array}$ & $\begin{array}{c}\text { empty container } \\
\text { stacker }\end{array}$ & $\begin{array}{c}\text { container } \\
\text { forklift }\end{array}$ \\
\hline Average load rate & 0.2 & 0.18 & 0.33 & 0.33 \\
\hline
\end{tabular}

\section{Calculation results}

\subsection{Calculation results for dynamic method}

The formula (1) was used to calculate the emission of pollutants other than $\mathrm{SO}_{2}$ of port operation machinery, and the formula (3) was used to calculate $\mathrm{SO}_{2}$ emission. The emission factors in Table 3 and the average engine load rate in Table 6 were selected.

The calculation results are shown in Table 7.

Table 7. Air pollutant emission inventory of port operation machinery by dynamic method (t).

\begin{tabular}{|c|c|c|c|c|c|c|c|}
\hline Machinery & $\begin{array}{l}\text { Power } \\
\text { section }\end{array}$ & $\begin{array}{l}\text { Emission } \\
\text { standard }\end{array}$ & $\mathrm{CO}$ & $\mathrm{HC}$ & NOx & PM & $\mathrm{SO}_{2}$ \\
\hline \multirow{5}{*}{$\begin{array}{l}\text { rubber-tyred } \\
\text { container } \\
\text { gantry crane }\end{array}$} & $75-130$ & China 2 & 3.47 & 0.69 & 4.17 & 0.21 & 0.0076 \\
\hline & kW & China 3 & 0.21 & 0.04 & 0.13 & 0.01 & 0.0015 \\
\hline & \multirow{3}{*}{$\begin{array}{l}>130 \\
\mathrm{~kW}\end{array}$} & China 1 & 42.42 & 11.03 & 78.05 & 4.58 & 0.0320 \\
\hline & & China 2 & 41.41 & 11.83 & 70.98 & 2.37 & 0.0459 \\
\hline & & China 3 & 14.31 & 3.82 & 13.36 & 0.86 & 0.0224 \\
\hline & Subtotal & & 101.8 & 27.4 & 166.7 & 8.0 & 0.109 \\
\hline $\begin{array}{l}\text { container front } \\
\text { lifting crane }\end{array}$ & $\begin{array}{c}>130 \\
\mathrm{~kW}\end{array}$ & China 2 & 2.75 & 0.79 & 4.71 & 0.16 & 0.0032 \\
\hline \multirow{4}{*}{$\begin{array}{l}\text { empty } \\
\text { container } \\
\text { stacker }\end{array}$} & Subtotal & & 2.7 & 0.8 & 4.7 & 0.2 & 0.0032 \\
\hline & $>130$ & China 2 & 8.96 & 2.56 & 15.35 & 0.51 & 0.0059 \\
\hline & $\mathrm{kW}$ & China 3 & 12.87 & 3.43 & 12.01 & 0.77 & 0.0107 \\
\hline & Subtotal & & 21.8 & 6.0 & 27.4 & 1.3 & 0.0166 \\
\hline \multirow{3}{*}{$\begin{array}{l}\text { container } \\
\text { forklift }\end{array}$} & $37-75$ & China 2 & 0.65 & 0.17 & 0.91 & 0.05 & 0.0007 \\
\hline & kW & China 3 & 0.37 & 0.08 & 0.29 & 0.03 & 0.0003 \\
\hline & $\begin{array}{c}75-130 \\
\mathrm{~kW}\end{array}$ & China 3 & 0.09 & 0.02 & 0.05 & 0.00 & 0.0001 \\
\hline
\end{tabular}




\begin{tabular}{ccccccc}
\hline$>130$ & China 1 & 0.14 & 0.04 & 0.26 & 0.02 & 0.0000 \\
$\mathrm{~kW}$ & China 2 & 0.20 & 0.06 & 0.35 & 0.01 & 0.0001 \\
Subtotal & & 1.4 & 0.4 & 1.9 & 0.1 & 0.0011 \\
Total & & 127.8 & 34.5 & 200.6 & 9.6 & 0.1303 \\
\hline
\end{tabular}

\subsection{Calculation results for fuel consumption method}

The formula (2) was used to calculate the emission of pollutants other than $\mathrm{SO}_{2}$ of port operation machinery, and the formula (3) was used to calculate $\mathrm{SO}_{2}$ emission. The emission factors in Table 4 were selected.

The calculation results are shown in Table 8.

Table 8. Air pollutant emission inventory of port operation machinery by fuel consumption method

(t).

\begin{tabular}{|c|c|c|c|c|c|c|c|}
\hline Machinery & $\begin{array}{l}\text { Power } \\
\text { section }\end{array}$ & $\begin{array}{l}\text { Emission } \\
\text { standard }\end{array}$ & $\mathrm{CO}$ & $\mathrm{HC}$ & NOx & PM & $\mathrm{SO}_{2}$ \\
\hline \multirow{5}{*}{$\begin{array}{l}\text { rubber-tyred } \\
\text { container } \\
\text { gantry crane }\end{array}$} & $75-130$ & China 2 & 9.09 & 1.82 & 10.92 & 0.55 & 0.0076 \\
\hline & kW & China 3 & 1.66 & 0.29 & 1.03 & 0.09 & 0.0015 \\
\hline & \multirow{3}{*}{$\begin{array}{c}>130 \\
\mathrm{~kW}\end{array}$} & China 1 & 39.94 & 10.38 & 73.49 & 4.31 & 0.0320 \\
\hline & & China 2 & 40.13 & 11.47 & 68.79 & 2.29 & 0.0459 \\
\hline & & China 3 & 16.82 & 4.49 & 15.70 & 1.01 & 0.0224 \\
\hline \multirow{3}{*}{$\begin{array}{l}\text { container front } \\
\text { lifting crane }\end{array}$} & Subtotal & & 107.6 & 28.4 & 169.9 & 8.3 & 0.109 \\
\hline & $\begin{array}{c}>130 \\
\mathrm{~kW}\end{array}$ & China 2 & 2.80 & 0.80 & 4.80 & 0.16 & 0.0032 \\
\hline & Subtotal & & 2.8 & 0.8 & 4.8 & 0.2 & 0.0032 \\
\hline \multirow{5}{*}{$\begin{array}{l}\text { empty } \\
\text { container } \\
\text { stacker }\end{array}$} & $>130$ & China 2 & 5.18 & 1.48 & 8.87 & 0.30 & 0.0059 \\
\hline & $\mathrm{kW}$ & China 3 & 8.00 & 2.13 & 7.47 & 0.48 & 0.0107 \\
\hline & Subtotal & & 13.2 & 3.6 & 16.3 & 0.8 & 0.0166 \\
\hline & $37-75$ & China 2 & 0.76 & 0.20 & 1.06 & 0.06 & 0.0007 \\
\hline & kW & China 3 & 0.27 & 0.06 & 0.21 & 0.02 & 0.0003 \\
\hline \multirow[t]{5}{*}{$\begin{array}{l}\text { container } \\
\text { forklift }\end{array}$} & $\begin{array}{c}75-130 \\
\mathrm{~kW}\end{array}$ & China 3 & 0.05 & 0.01 & 0.03 & 0.00 & 0.0001 \\
\hline & $>130$ & China 1 & 0.03 & 0.01 & 0.05 & 0.00 & 0.0000 \\
\hline & $\mathrm{kW}$ & China 2 & 0.07 & 0.02 & 0.12 & 0.00 & 0.0001 \\
\hline & Subtotal & & 1.2 & 0.3 & 1.5 & 0.1 & 0.0011 \\
\hline & Total & & 124.8 & 33.2 & 192.6 & 9.3 & 0.1303 \\
\hline
\end{tabular}

\subsection{Comparison of calculation results}

The calculation results of dynamic method and fuel consumption method are compared and analyzed. The results are shown in Table 9.

It can be seen from the table that in general, the calculation results of the emission inventory of air pollutants from port operation machinery of container terminals calculated by the power method and the fuel consumption method are very close. The calculation deviations of the overall emission inventory of $\mathrm{CO}, \mathrm{HC}$, NOx and PM are - 2.3\%, - 3.8\%, $4.0 \%$ and $-3.1 \%$, respectively.

According to the type of machinery, the deviation between the calculation results of RTG and frontal crane is small. The calculation deviations of $\mathrm{CO}, \mathrm{HC}, \mathrm{NOx}$ and PM emission inventory of RTG are $5.7 \%, 3.6 \%, 1.9 \%$ and $3.8 \%$ respectively, while those of frontal crane are $3.7 \%, 0.0 \%, 2.1 \%$ and $0.0 \%$, respectively. The deviation between the calculation results of Empty Container Stacker and forklift truck is relatively large, but both 
are less than $50 \%$, which is also within the acceptable range. The calculation deviations of $\mathrm{CO}, \mathrm{HC}, \mathrm{NOx}$ and PM emission inventory of Empty Container Stacker are $-39.4 \%,-40.0 \%$, $-40.5 \%,-38.5 \%$, respectively, while those of forklift truck are $-14.3 \%,-25.0 \%,-21.1 \%$ and $0.0 \%$, respectively.

Table 9. Comparison of calculation results between dynamic method and fuel consumption method.

\begin{tabular}{|c|c|c|c|c|c|}
\hline \multicolumn{2}{|c|}{ Machinery } & $\mathrm{CO}$ & $\mathrm{HC}$ & NOx & PM \\
\hline rubber-tyred & Dynamic method(t) & 101.8 & 27.4 & 166.7 & 8 \\
\hline \multirow{2}{*}{$\begin{array}{l}\text { container gantry } \\
\text { crane }\end{array}$} & Fuel consumption method(t) & 107.6 & 28.4 & 169.9 & 8.3 \\
\hline & Relative deviation $(\%)$ & 5.7 & 3.6 & 1.9 & 3.8 \\
\hline \multirow{3}{*}{$\begin{array}{l}\text { container front } \\
\text { lifting crane }\end{array}$} & Dynamic method $(\mathrm{t})$ & 2.7 & 0.8 & 4.7 & 0.2 \\
\hline & Fuel consumption method(t) & 2.8 & 0.8 & 4.8 & 0.2 \\
\hline & Relative deviation(\%) & 3.7 & 0.0 & 2.1 & 0.0 \\
\hline \multirow{3}{*}{$\begin{array}{l}\text { empty container } \\
\text { stacker }\end{array}$} & Dynamic method(t) & 21.8 & 6 & 27.4 & 1.3 \\
\hline & Fuel consumption method(t) & 13.2 & 3.6 & 16.3 & 0.8 \\
\hline & Relative deviation $(\%)$ & -39.4 & -40.0 & -40.5 & -38.5 \\
\hline \multirow{3}{*}{ container forklift } & Dynamic method(t) & 1.4 & 0.4 & 1.9 & 0.1 \\
\hline & Fuel consumption method(t) & 1.2 & 0.3 & 1.5 & 0.1 \\
\hline & Relative deviation(\%) & -14.3 & -25.0 & -21.1 & 0.0 \\
\hline \multirow{3}{*}{ Total } & Dynamic method(t) & 127.8 & 34.5 & 200.6 & 9.6 \\
\hline & Fuel consumption method(t) & 124.8 & 33.2 & 192.6 & 9.3 \\
\hline & Relative deviation(\%) & -2.3 & -3.8 & -4.0 & -3.1 \\
\hline
\end{tabular}

\section{Conclusion}

In this paper, the classification of port operation machinery, the calculation method of dynamic method and fuel consumption method, emission factor, activity level and other aspects of port operation machinery air pollutant emission inventory are comprehensively sorted out, and the calculation method system of port operation machinery air pollutant emission list is established.

Through the special investigation of port machinery manufacturers and engine manufacturers, the average load rate data of main port machinery engines in domestic container terminals are obtained.

The actual emissions of a domestic container port are calculated and compared by using dynamic method and fuel consumption method respectively. The results show that the calculation method system of air pollutant emission inventory of port operation machinery established in this paper is highly practical, and the calculation results obtained by the two methods are very close.

This work was financially supported by Green Intelligent Inland Ship Innovation Program and National Key Research and Development Program (2016YFC0205206) fund and Key Research Project of Science \& Technology Assisting Economy 2020 "Research and application of active monitoring equipment for ship air pollutant emission".

\section{References}

1. Peng Yiqiang, Feng Xuejun, Gu Jian, et al. Study on mechanical emission inventory of container port based on engine activity [J]. Journal of safety and environment, 2017 (3): 1136-1141

2. Tan Hua, Liu Juan, Shen Yin, et al. Study on emission inventory of mechanical air pollutants from port and dock [J]. Environmental science and management, 2013038 (006): 82-87102 
3. Jia Xu, Feng Xuejun, Jiang liupeng. Study on air pollutant emission from port operation machinery [J]. Journal of East China Jiaotong University, 2014 (3): 12-17

4. Fan Xiaoli, Xia Zequn, Li Cheng, et al. Improvement and application of port machinery emission inventory estimation method [J]. Environmental science research, 2017 (4): 628-635

5. Ministry of environmental protection of the people's Republic of China. Technical Guide for Compilation of Emission Inventory of Air Pollutants from Non-road Mobile Sources (Trial) [S] 2014

6. Ministry of Ecological Environment of the people's Republic of China. The Revised List of Emission Limits and Measurement Methods of Exhaust Pollutants from Diesel Engines for Non-road Mobile Machinery (China's III and IV stages) (GB 20891-2014) (Draft for comments) [S] 2019

7. General Administration of quality supervision, inspection and Quarantine of the people's Republic of China, National Standardization Administration of China.GB 19147-2016, vehicle diesel [S] 2016

8. Ministry of environmental protection, General Administration of quality supervision, inspection and Quarantine of the people's Republic of China. GB 20891-2014, Emission Limits and Measurement Methods of Exhaust Pollutants from Diesel Engines for Non-road Mobile Machinery (China's III and IV stages) [S] 2014 